\title{
Review Article \\ Targeting Th17 Cells with Small Molecules and Small Interference RNA
}

\author{
Hui Lin, ${ }^{1}$ Pingfang Song, ${ }^{2}$ Yi Zhao, ${ }^{1}$ Li-Jia Xue, ${ }^{1}$ Yi Liu, ${ }^{1}$ and Cong-Qiu Chu ${ }^{2}$ \\ ${ }^{1}$ Department of Rheumatology and Immunology, West China Hospital, Sichuan University, Chengdu, Sichuan 610041, China \\ ${ }^{2}$ Division of Arthritis and Rheumatic Diseases, Oregon Health \& Science University and VA Portland Health Care System, \\ Portland, OR 97239, USA \\ Correspondence should be addressed to Yi Liu; yi2006liu@163.com and Cong-Qiu Chu; chuc@ohsu.edu
}

Received 25 September 2015; Accepted 30 November 2015

Academic Editor: Nina Ivanovska

Copyright (C) 2015 Hui Lin et al. This is an open access article distributed under the Creative Commons Attribution License, which permits unrestricted use, distribution, and reproduction in any medium, provided the original work is properly cited.

\begin{abstract}
T helper 17 (Th17) cells play a central role in inflammatory and autoimmune diseases via the production of proinflammatory cytokines interleukin- (IL-) 17, IL-17F, and IL-22. Anti-IL-17 monoclonal antibodies show potent efficacy in psoriasis but poor effect in rheumatoid arthritis (RA) and Crohn's disease. Alternative agents targeting Th17 cells may be a better way to inhibit the development and function of Th17 cells than antibodies of blocking a single effector cytokine. Retinoic acid-related orphan receptor gamma t $(\mathrm{ROR} \gamma \mathrm{t})$ which acts as the master transcription factor of Thl7 differentiation has been an attractive pharmacologic target for the treatment of Th17-mediated autoimmune disease. Recent progress in technology of chemical screen and engineering nucleic acid enable two new classes of therapeutics targeting ROR $\gamma$ t. Chemical screen technology identified several small molecule specific inhibitors of ROR $\gamma t$ from a small molecule library. Systematic evolution of ligands by exponential enrichment (SELEX) technology enabled target specific aptamers to be isolated from a random sequence oligonucleotide library. In this review, we highlight the development and therapeutic potential of small molecules inhibiting Th17 cells by targeting ROR $\gamma \mathrm{t}$ and aptamer mediated CD $4^{+}$ $\mathrm{T}$ cell specific delivery of small interference RNA against ROR $\gamma \mathrm{t}$ gene expression to inhibit pathogenic effector functions of Th17 lineage.
\end{abstract}

\section{Introduction}

The differentiation of naïve $\mathrm{CD} 4^{+} \mathrm{T}$ cells into effector $\mathrm{T}$ helper (Th) cells is induced by their T cell receptor and costimulatory molecules in the presence of other cytokines. It is that these cytokines and transcriptional factors ultimately determine the differentiation of $\mathrm{CD} 4^{+}$Th cells into distinct subsets. Initially, $\mathrm{CD} 4^{+}$Th cells were identified as having two subsets, Th1 and Th2 cells [1]. Th1 cells produce high levels of IFN$\gamma$ and express the transcriptional factor T-bet, which protect the host against intracellular pathogens [2]. Th2 cells express GATA-3 and produce IL-4, IL-5, IL-9, and IL-13 which are mainly involved in protection against parasitic helminthes [3]. Recently, new subsets of effector Th cells that express different transcriptional factors and produce distinct cytokines have been discovered, including $\mathrm{T}$ regulatory (Treg) cells, Th17 cells, follicular helper T cell (Tfh), and Th9 cells $[4,5]$. Treg cells are characterized by the production of IL-10 and
TGF- $\beta$ as major cytokines and expression of forkhead box P3 (Foxp3) as transcriptional factor, which control immune response and maintain immune tolerance [6]. Th17 cells are characterized by the production of IL-17A (also known as IL17), IL-17F, and IL-22 as signature cytokines and expression of retinoic acid-related orphan receptor gamma t (ROR $\gamma \mathrm{t})$ as master transcriptional factor [7-9]. These cytokines play a critical role in host defense against extracellular pathogens such as bacteria and fungi [10] and many autoimmune diseases, including psoriasis, rheumatoid arthritis (RA), inflammatory bowel disease, uveitis, and multiple sclerosis [11-13]. Fully human monoclonal antibodies (mAbs) against IL-17 (ixekizumab and secukinumab) and IL-17 receptor A (IL-17RA) (brodalumab) have rapidly reduced clinical symptoms in patients with psoriasis [14-18]. However, in a Phase IB study on methotrexate-resistant RA patients, brodalumab did not improve disease symptoms [19]. In a Phase II study, secukinumab did not show clinical efficacy 
in RA patient with inadequate response to methotrexate [20]. Furthermore, treatment of patients with Crohn's disease with secukinumab not only showed no good responses, but also worsened disease in some patients [21]. These data suggest that targeting IL-17 cannot completely alleviate Th17mediated autoimmune diseases. Since Th17 cells also produce other cytokines such as IL-17F and IL-22 which are potent inflammatory mediators, targeting Th17 cells may provide a better efficacy in these clinical conditions [22].

Th17 differentiation requires the master transcriptional factor, $\operatorname{ROR} \gamma \mathrm{t}$, which is induced by activation of naïve $\mathrm{CD}^{+} \mathrm{T}$ cells in the presence of inflammatory cytokines, such as IL-6, TGF- $\beta$, IL-21, IL-1 $\beta$, and IL-23 [23]. Mice deficient in ROR $\gamma \mathrm{t}$ have reduced Thl7 differentiation and are resistant to experimental autoimmune encephalomyelitis (EAE) [9]. Conversely, overexpression of ROR $\gamma t$ promotes IL-17 production. The critical role of ROR $\gamma \mathrm{t}$ in the generation of Thi7 cells provides a unique opportunity to develop novel therapeutics targeting Th17 cells. Given the fact that cytokines of IL-17 family are important in host defense and they are also produced by other immune cells other than Th17 cells, it is highly desirable to target the pathogenic Th17 cells. The disadvantage of mAbs targeting individual IL-17 cytokines is that it does not discriminate the cellular source of IL-17 and therefore poses potential adverse effects from blocking IL17 activity produced for host defense. Moreover, the effector cytokines of Th17 cells include IL-17A, IL-17F, and IL-22 which are all to be blocked to abrogate Th17 cell activity which is a challenging task for individual mAbs.

Recently, small molecules targeting ROR $\gamma \mathrm{t}$ have been identified, which not only suppress Th17 differentiation and IL-17 production, but also reduce the severity of animal models of autoimmune diseases. In addition, recent advancement in technology of engineering nucleic acid enables a targeted delivery of small interference RNA (siRNA) or short hairpin RNA (shRNA) using aptamers which serve as vehicle to guide siRNA or shRNA to target cells. These two classes of agents, which are nonmonoclonal antibody or fusion protein based, are emerging to be useful in targeting Th17 cells rather than merely blocking individual cytokines. Small molecules directly interact with ROR $\gamma$ t to block its activity while siRNA/shRNA specifically inhibits ROR $\gamma$ t gene expression.

\section{Identification and Differentiation of Th17 Cells}

Before the identification of Th17 cells, T cell mediated autoimmunity was believed to be mediated by Th1 cells. Indeed, T-bet deficient mice were resistant to EAE, and polyclonal antibody targeting IL-12 was an effective therapy for EAE and CIA. However, the later studies provided contradictory results that IFN- $\gamma$ and IFN- $\gamma$ receptor deficient mice, as well as mice that lack IL-12p35, were not protected from EAE but developed rapidly progressing disease [24, 25]. Furthermore, IFN- $\gamma$ knockout mice develop severe EAE and convert resistant strain of mice to be highly susceptible to collagen-induced arthritis (CIA) [26, 27]. Thus, the function of Thl cells in $\mathrm{T}$ cell mediated autoimmunity was challenged.
The discovery of IL-23, a cytokine which is composed of a unique p19 subunit and a p40 subunit which is shared with IL-12 [28], provided us with novel insights. It was IL-23, not IL-12, that was critical for the induction of EAE and CIA $[29,30]$. Moreover, IL-23 failed to induce IFN- $\gamma$ but instead expanded IL-17-producing T cells. When IL-17-producing T cells induced by IL-23 were adoptively transferred into naïve wild-type mice, EAE developed [30]. IL-23p19-deficient mice were resistant to EAE due to lack of IL-17-producing T cells $[29,30]$. These studies led to IL-17-producing T cells to be described as a distinct Th cell subset, which was named Th17 cells $[7,8]$.

Differentiation of Th17 cells is induced by activation of naive $\mathrm{CD}^{+} \mathrm{T}$ cells in the presence of inflammatory cytokines. Transforming growth factor- (TGF-) $\beta$ is a regulatory cytokine which has multiple effects on $\mathrm{T}$ cell development, homeostasis, and tolerance [31]. TGF- $\beta$ not only induces naïve precursors into Foxp3-expressing inducible Treg (iTreg) [30], but also plays a crucial role in the generation of Th17 [31]. However, TGF- $\beta$ alone is not capable of the induction of Th17 cells development. Unlike Th1, Th2, and iTreg cells, which only require a single cytokine for their generation, additional differentiation factors are required in Th17 cells development. Recent studies found that combination of IL- 6 and TGF- $\beta$ was the essential cytokine-mix of inducing naïve $\mathrm{T}$ cells to develop Th17 cells [32-34]. IL6 is able to inhibit TGF- $\beta$-driven induction of Foxp3 in naïve $\mathrm{T}$ cells and instead leads to strong induction of IL-17 [33]. Furthermore, IL-21 together with TGF- $\beta$ is also able to induce the differentiation of Th17 cells. During the initial Th17 differentiation, IL- 6 induced IL-21 acting as a positive amplification loop to enforce Th17 differentiation [35, 36]. IL-21 was shown to be able to replace IL-6 at least in vitro [37]. In the absence of IL-6, IL-21 together with TGF- $\beta$ was able to inhibit the development of iTreg and to promote the differentiation of Th17 cells [37]. In vivo, however, the role of IL-21 in the induction of Th17 cells remains controversial. It had been reported that the absence of IL-21 or IL-21R had no significant difference on the development of Th17 cells $[38,39]$. Thus, IL-21 might be an alternative pathway in inducing and expanding Th17 cells [23]. IL-23 also plays an important role in regulation of Th17 cells indirectly. However, IL-23 receptors are absent on naïve T cells, so IL-23 is not involved in the initiation of Th17 cells, but expands an existing population of effector Th17 cells [40]. Without IL-23, activated $\mathrm{CD}^{+}{ }^{+} \mathrm{T}$ cells in the presence of IL- 6 plus TGF- $\beta$ were able to produce high amounts of IL-17 but did not fully develop into pathogenic Th17 cells [41]. The treatment with neutralizing IL-23p19 specific antibody not only inhibited the development of EAE but also ameliorated EAE after the onset of disease [42]. Ustekinumab, a mAb against IL-23/IL-12p40, has shown a marked efficacy in clinical studies involving psoriasis patients [43]. Ustekinumab also has shown increased clinical responses in patient with tumor necrosis factor- (TNF-) refractory Crohn's disease [44]. These studies indicate that IL-23 is an important cytokine in Th17-mediated autoimmune disease. In contrast to mice, combination of IL- 6 and TGF- $\beta$ is not capable of inducing human Th17 differentiation [45]. Instead of TGF- $\beta$, IL-1 $\beta$ 
together with IL- 6 or IL-23 was reported to upregulate ROR $\gamma \mathrm{t}$ and induce IL-17 production from $\mathrm{CD} 4^{+} \mathrm{T}$ cells isolated from human peripheral blood, suggesting a fundamental difference in the biology of human and mouse Th17 cells [46].

\section{Transcriptional Regulation of Th17 Cells}

The differentiation of Th17 cells is initiated by the combined signals of activated TCR and cytokine receptors. These signals then induce specific transcription factors responsible for the expression of Thl7 cell specific genes such as Ill7 and Illif. Multiple transcription factors have been shown to be important for the development of Th17 cells, including ROR $\gamma$ t, STAT3, IRF4, BATF, and RUNX1. ROR $\gamma \mathrm{t}$ is the master transcription factor that regulates the differentiation of Th17 cells [47]. ROR $\gamma$ t belongs to the ROR subfamily. ROR is the member of retinoic acid nuclear receptor superfamily containing a ligand-binding domain (LBD). Usually, ligand binding to the LBD of ROR leads to conformational change and transcriptional activity. The ROR subfamily has three members in mammals: $\operatorname{ROR} \alpha, \operatorname{ROR} \beta$, and $\operatorname{ROR} \gamma$ [48]. The ROR $\gamma$ has two different isoforms: ROR $\gamma$ and ROR $\gamma$ t, which are encoded by the Rorc gene and have difference only at their $\mathrm{N}$ terminus [49]. ROR $\gamma \mathrm{t}$ is a splice variant of ROR $\gamma$ expressed in T cells [49]. Unlike ROR $\gamma$, which is expressed in many tissue such as heart, kidney, liver, lung, brain, and muscle, ROR $\gamma \mathrm{t}$ is expressed exclusively in lymphoid cells [50]. $\mathrm{ROR} \gamma \mathrm{t}$ is an important molecule to regulate gene expression during the development of $\mathrm{T}$ cells and the formation of secondary lymphoid organ [51-53]. Rorc gene knockout mice exhibited that $\mathrm{CD} 4^{+} \mathrm{CD}^{+}$thymocytes showed early apoptosis, and lymph nodes, Peyer's patches, and lymphoid tissue inducer (LTi) cells failed to develop [52, 53]. In vitro, with the absence of Rorc in $\mathrm{CD} 4^{+} \mathrm{T}$ cells, IL-17 expression was greatly decreased under Th17 polarizing conditions. Conversely, overexpression of ROR $\gamma \mathrm{t}$ in naïve $\mathrm{CD} 4^{+} \mathrm{T}$ cells was sufficient to induce the expression of IL-17, IL-17F, and IL22 [9]. ROR $\gamma t$ is necessary for the expression of IL-17 as well as the differentiation of Th17 in mouse and human $\mathrm{CD} 4^{+} \mathrm{T}$ cells $[9,54]$. The number of Th17 cells was markedly reduced and the disease severity of EAE alleviated in Rorc-deficient mice. The role of ROR $\gamma \mathrm{t}$ is similar to transcription factors such as T-bet and GATA 3 in Th1 and Th2 differentiation, respectively, and therefore ROR $\gamma \mathrm{t}$ has been considered to be a "master transcriptional factor" for Th17 differentiation [47]. ROR $\gamma \mathrm{t}$ promotes IL-17 expression by directly binding the promoter region of Ill7 gene at multiple sites $[9,55,56]$.

Another related retinoic acid nuclear receptor, $\operatorname{ROR} \alpha$, is also expressed in Th17 cells both in vitro and in vivo. In contrast to ROR $\gamma \mathrm{t}, \mathrm{ROR} \alpha$ played minimal roles in mouse Th17 differentiation. However, mice deficiencies in Rora and Rorc markedly impaired Th17 generation and completely protected mice from EAE [57]. The coexpression of Rora and Rorc induced greater Th17 differentiation. It is demonstrated that ROR $\alpha$ and ROR $\gamma$ t acts as synergy in regulating Th17 cell gene expression.

Besides ROR $\alpha$ and ROR $\gamma$ t, other transcription factors are required in Th17 differentiation. The transcription factor signal transducer and activator of transcription 3 (STAT3), which is preferentially activated by IL-6, IL-21, and IL-23, is capable of inducing ROR $\gamma \mathrm{t}$ and regulating Th17 cells development $[58,59]$. Deficiency of STAT3 in $\mathrm{CD}^{+}{ }^{+} \mathrm{T}$ cells impaired Th17 differentiation in vivo, and overexpression of a constitutively active STAT3 could increase IL-17 production $[58,60]$. STAT3 might affect the production of IL-17 by increasing the expression of $\operatorname{ROR} \gamma \mathrm{t}$ and $\operatorname{ROR} \alpha[57,58]$. Furthermore, STAT3 also binds directly to the Ill7 and Il21 promoters and leads to the expression of IL-17 and IL-21 $[61,62]$. Therefore, STAT3 and ROR $\gamma \mathrm{t}$ seem to cooperate to induce IL-17 production. Transcription factor interferon regulatory factor 4 (IRF4) also has a certain role in Th17 differentiation, which was previously associated with GATA3 expression in Th2 differentiation [63]. Recently, it has been shown that IRF4 regulates IL-17 and IL-21 production [64]. IRF-4 deficient mice were shown to impair Thl7 responses and were resistant to EAE [65]. IRF- 4 deficient $T$ cells failed to upregulate ROR $\gamma \mathrm{t}$ in response to IL- 6 plus TGF- $\beta$ and did not differentiate into Thl7 cells [65], suggesting that IRF4 might also cooperate with ROR $\gamma$ t to induce Th17 differentiation. In addition, BATF, a member of the AP-1 transcription factor family, and Runxl, a member of RUNX1 transcription factor, are also important for Th17 differentiation $[66,67]$.

As mentioned above, ROR $\gamma$ t, STAT3, IRF4, BATF, and RUNX1-deficient mice show an impaired Th17 generation and an attenuated susceptibility to the induction of autoimmunity. Targeting these transcription factors might be a possible way to inhibit the development and function of Th17 cells. ROR $\gamma t$ acts as the master transcription factor of Th17 differentiation, resulting in an attractive pharmacologic target for the treatment of Th17-mediated autoimmune disorders.

\section{Small Molecules Target to Th17 Cells}

4.1. Digoxin. By performing a chemical screen with an insect cell-based reporter assay, the cardiac glycoside digoxin was identified as a specific inhibitor of $\operatorname{ROR} \gamma \mathrm{t}$ transcriptional activity. Digoxin suppressed murine Th17 cell differentiation without affecting differentiation of other $\mathrm{T}$ cell lineages. In addition, digoxin was effective in attenuating EAE in mice and in delaying the onset and reducing disease severity in a rat model of adjuvant-induced arthritis [68-70]. Digoxin was toxic for human cells at high doses, but its synthetic derivatives 20,22-dihydrodigoxin-21,23-diol and digoxin-21salicylidene were nontoxic and specifically inhibited the induction of IL-17 in human $\mathrm{CD}^{+} \mathrm{T}$ cells [68]. These data indicate that derivatives of digoxin might be used as chemical templates for the development of targeting ROR $\gamma \mathrm{t}$ therapeutic agents that attenuate inflammatory Th17 cells function and autoimmune disease.

4.2. ML209/Compound 4n. Using a cell-based gene ROR $\gamma \mathrm{t}$ and control reporter assay, a small molecule library comprising 300,000 compounds was screened at the NIH Chemical Genomics Center (NCGC), a series of diphenylpropanamide compounds as a selective ROR $\gamma$ t inhibitor, including a highly potent compound ML209 (also known as compound 4n). 
Huh and colleagues found that compound $4 \mathrm{n}$ inhibited transcriptional activity of $\operatorname{ROR} \gamma \mathrm{t}$, but not $\mathrm{ROR} \alpha$, in cells. Like digoxin, compound 4n selectively inhibited murine Th17 differentiation without affecting the differentiation of naïve $\mathrm{CD}^{+}{ }^{+} \mathrm{T}$ cells into other lineages, including Th1 and regulatory T cells. Moreover, compound $4 \mathrm{n}$ suppressed ROR $\gamma$ t-induced expression of IL-17 in human T cells [71]. This report demonstrates that compound $4 \mathrm{n}$ might serve as a valuable pharmacological agent to inhibit ROR $\gamma$ t transcriptional activity and Th17 differentiation.

4.3. SR1001 and SR2211. Using the liver X receptor (LXR) agonist T0901317 [72] scaffold as a lead compound, Griffin and Burris developed a derivative, SR1001, which was devoid of all LXR activity yet retained its ability to suppress the transcriptional activity of ROR $\alpha$ and ROR $\gamma$ [73]. SR1001 not only is high-affinity synthetic ligand that is specific to both $\operatorname{ROR} \alpha$ and $\operatorname{ROR} \gamma$, but also inhibits Thl7 cell differentiation and function. SR1001 binds specifically to the LBD of ROR $\alpha$ and $\operatorname{ROR} \gamma$, inducing a conformational change within the $\mathrm{LBD}$, resulting in suppression of the receptors' transcriptional activity. By suppressing IL-17 gene expression and protein production, SR1001 inhibited the development of murine Th17 cells. Furthermore, SR1001 inhibited the expression of cytokines in murine or human Th17 cells and effectively reduced EAE severity in mice [73]. Therefore, SR1001 and its derivatives may represent a novel drug to treat not only Th17-mediated autoimmune diseases, but ROR-mediated metabolic diseases as well.

By modifying the SR1001 scaffold, SR2211 was developed. Unlike SR1001, SR2211 can specifically inhibit the transcriptional activity of $\operatorname{ROR} \gamma$, but not $\operatorname{ROR} \alpha$. In cotransfection assays, SR2211 suppresses transcription activity in both GAL4-ROR $\gamma$ LBD and full-length $\operatorname{ROR} \gamma$ contexts. Furthermore, SR2211 could result in suppression of gene expression and production of IL-17 in EL-4 cells [74]. These data strongly suggest that SR2211 is also a potent and efficacious ROR $\gamma$ mediator and represses its activity. Moreover, SR2211 suppressed inflammatory T cell function and Th17 cell differentiation and markedly reduced joint inflammation in mice with CIA [75]. It is shown that SR2211 has the potential utility for the treatment of Th17-mediated autoimmune disorders.

4.4. Ursolic Acid. Ursolic acid (UA), a small molecule present in herbal medicine, was identified by screening a small chemical library. In treatment with UA, the function of ROR $\gamma \mathrm{t}$ was inhibited selectively and effectively, and IL-17 expression was greatly decreased in developing and differentiated Th17 cells. In addition, UA ameliorated EAE in mice. The results thus indicate that UA might be a valuable drug candidate and can be used for developing treatments of Th17-mediated inflammatory diseases [76].

4.5. TM920, TMP778, and GSK805. Using a fluorescence resonance energy transfer (FRET) assay and two-cell line reporter assay (IL-17F promoter and ROR $\gamma$-LBD promoter assays), a proprietary small-molecule library was screened and several compounds binding to ROR $\gamma$ t were identified. TM920 and TM778 were identified as highly potent and selective ROR $\gamma \mathrm{t}$ inhibitors [77, 78]. In vitro, TM920 and TM778 suppressed Th17 development and inhibited IL17 production from differentiated Th17 cells. Furthermore, TMP778 has increased potency and specificity for Th17 differentiation, resulting in blockade of nearly all Th17 signature gene expression [77]. Importantly, TMP778 displays no activity against any of the other 24 nuclear receptors tested, including $\operatorname{ROR} \alpha$ and $\operatorname{ROR} \beta$, so TMP778 has very limited effects on the expression of other genes [78]. TMP778 potently impaired the IL-17 production not only by human $\mathrm{CD}^{+}$Th17 cells, but also by human $\mathrm{CD}^{+}$Tc17 cells, memory $\mathrm{CD}^{+} \mathrm{T}$ cells, and PBMCs. TMP778 also blocked IL-17 production by skin mononuclear cells of psoriasis patients and significantly impaired expression of Th17 signature gene from psoriasis patients [78]. In vivo, TMP778 suppressed imiquimod-induced cutaneous inflammation and EAE [77, 78]. Although the specific ROR $\gamma$ t inverse agonist, TM778, may have good ROR $\gamma \mathrm{t}$ target effects and low off-target effects, unexpected toxicity may occur in nonimmune cells and tissues (see below); in particular, it required a relatively higher dose of TN778 to exert its function. Another ROR $\gamma \mathrm{t}$ inhibitor, GSK805, is proved to be more potent than TM778 and can be orally administered. GSK805 could efficiently ameliorate the severity of EAE and strongly inhibited Th17 cell differentiation in the central nervous system [77]. It is interesting but unexpected that TMP778 and GSK805 were able to induce ROR $\gamma$ t biding to GATA 3 and led to an increase of GATA3 mRNA and protein expression. The apparent transactivation of GATA3 by ROR $\gamma$ t may partially explain the inhibition of Th17 cell signature gene expression by TMP778 or GSK805 [77].

These compounds target ROR $\gamma$ t, which inhibit the transcriptional activity of ROR $\gamma$ t by binding to ROR $\gamma \mathrm{t}$ LBD [79], a domain present in both ROR $\gamma$ and ROR $\gamma$ t. These compounds not only inhibit Th17 cell differentiation and IL-17 production, but also have shown variable levels of efficacy in EAE and CIA studies. Therefore, these compounds may serve as novel attractive drugs to treat Th17-mediated autoimmune disorders. However, we should note that ROR $\gamma$ is broadly expressed in many human tissues such as heart, kidney, liver, lung, brain, and muscle, so $\operatorname{ROR} \gamma / \operatorname{ROR} \gamma \mathrm{t}$ inverse agonists might induce toxicity via inhabitation of ROR $\gamma$ in nonimmune tissue. Thus, in order to treat Th17mediated autoimmune disorders, it is necessary to develop a specific strategy to only inhibit ROR $\gamma / \operatorname{ROR} \gamma \mathrm{t}$ transcriptional activity in immune cells, especially $\mathrm{CD} 4^{+} \mathrm{T}$ cells.

\section{Targeting Th17 Cells by CD4 Aptamer- ROR $\gamma t$ shRNA Chimera}

Recently, RNA interference (RNAi) technology provides a promise for studying basic $\mathrm{T}$ cell biology and for developing potential $\mathrm{T}$ cell targeted therapeutics. However, efficient delivery of small interference RNA (siRNA) into primary T cells remains a major hurdle of siRNA-based therapy [80]. Emergence of CD4 aptamers, which specifically bind CD $4^{+}$ $\mathrm{T}$ cells and efficiently deliver various biomolecules into these 
cells, makes it possible to target ROR $\gamma \mathrm{t}$ and IL-17 production in $\mathrm{CD}^{+}$Th17 cells with RNAi technology. Here we will discuss the advantage of aptamer-siRNA and contemplate whether CD4 aptamer-ROR $\gamma$ t shRNA chimeras would be beneficial to inhibit Th17 differentiation in human T cells.

5.1. Aptamers. Aptamers, nucleic acid-based ligands, are small single-stranded DNA or RNA oligonucleotides that are produced in vitro via a process known as systematic evolution of ligands by exponential enrichment (SELEX) [81, 82]. In the SELEX process, aptamers are selected from a large pool $\left(>1 \times 10^{14}\right)$ of single-stranded oligonucleotides with random sequences $[83,84]$. After the incubation of the random aptamers pool with the target, followed by repeated cycles: the fixation of region containing binding, PCR or RT-PCR amplification, and modification of restriction endonuclease, aptamers with high affinity with their corresponding ligands are cloned [85]. With the technological improvement in the SELEX process, researchers can isolate aptamers from not only a protein target but also a complex mixture including cell-surface proteins and human plasma in the past decades. Recently, isolation of cell- and receptor-specific aptamers using living cells has been reported [86-88]. Therefore, the power of SELEX enables one to generate specific aptamers against a molecule, a protein, a cell-surface receptor, and even a cell $[89,90]$. Notably, chemical modifications to aptamers, including sugar modifications $\left(2^{\prime}\right.$-O-Methyl, $2^{\prime}$-Omethoxyethyl, $2^{\prime}$-fluoro, or LNA), the phosphate backbone modifications (phosphorothioate, boranophosphate), or the nucleobase moiety modifications (4-thiouracil, 2-thiouracil, and diaminopurine), have been reported to greatly enhance the nuclease resistance of the aptamer probes [91, 92].

Similar to antibodies, aptamers, which are often regarded as nucleic acid "antibodies," gain entrance to target cells via receptor-mediated endocytosis upon binding to cell surface ligands [93, 94]. However, aptamers are generally nonimmunogenic or low-immunogenic $[95,96]$, whereas antibodies suffer from immunogenicity, resulting in immune responses in patients [97]. In addition, the cost of generation of aptamers in vitro is much less than the development process of antibodies [93, 98]. Importantly, aptamers can be generated through simple chemical approach in animals or cultured mammalian cells, making them easier to produce for large scale manufacturing that are necessary for clinical use [99]. The first therapeutic aptamer, antivascular endothelial growth factor (VEGF) aptamer, Macugen (pegaptanib) was approved by the US FDA for treatment of age related macular degeneration in 2005 [100]. Also, several aptamers are currently undergoing clinical trials $[92,101,102]$. Therefore, aptamers that target various proteins and cells are considered as ideal diagnostic and therapeutic approach for clinical disease, such as cancer, infection, and autoimmune disease $[99,103]$.

5.2. Aptamer-siRNA. RNAi offers a powerful approach to developing new therapeutics in human diseases [105]. siRNA, because of their ability to silence expression of sequencespecific gene $[106,107]$, has currently been developed as a new strategy in treatment of human disease. However, it is a big challenge to efficiently and safely deliver siRNA into "difficult-to-transfect" primary T cells by conventional transfection methods. For instance, electroporation and nucleofection cause excessive cell death and may require preactivation of $\mathrm{T}$ cells and electrical apparatus [108, 109]. Chemically modified synthetic siRNA with Acell agents can be transfected into primary $\mathrm{T}$ cells; however, they are needed to incubate with $\mathrm{T}$ cells for longer time and only a small portion of $\mathrm{T}$ cells are transfected [110]. The most disappointing defect of these methods is that it is difficult for them to be used in vivo. Retroviral vectors carrying shRNA cassette are able to effectively infect and enter $\mathrm{T}$ cells and make the shRNA to stably be expressed for the lifetime of the cells in vitro and in vivo [111, 112]. However, applying retroviral vectors in vivo gives rise to the danger about malignant transformation, which limits the viral vector transfection [80]. Nanoparticles are effective to deliver siRNA into $\mathrm{T}$ cells, but the delivery is not $\mathrm{T}$ cell specific [113]. Recently, a method that uses a fusion protein composed of a cell-target antibody fragment joined to a protamine peptide that binds nucleic acids has been reported for cellspecific siRNA transfection of immune cells [114, 115]. siRNAs mixed with the fusion protein can silence gene expression in cells, both in vitro and in tissues. Modifications of this approach effectively inhibit HIV infection in humanized mice [116]. However, antibody-based fusion proteins are expensive to manufacture, are potentially immunogenic, and are unsuitable for clinical use. Hence, an effective siRNA delivery system in vivo for targeting $\mathrm{T}$ cells has to be developed for treatment of $\mathrm{T}$ cells-mediated human disease. Because aptamers can enter target cells via endocytosis and maintain stability after endocytosis, aptamers have been developed as guiding moieties for both drug delivery and nucleic acid transport vehicles such as siRNA and shRNA [117]. Aptamer siRNA chimeras, composed of an siRNA/shRNA fused to an aptamer, provide an attractive alternative for in vitro and in vivo gene knockdown [118]. The aptamer portion of the chimeras binds to a cell-surface receptor such as prostate surface membrane Ag (PSMA), CD4, whereas the siRNA portion targets the overexpressed signaling molecules or regulatory nucleic acids, resulting in inhibition of cell proliferation and differentiation. Aptamer-siRNA chimeras (AsiCs) efficiently transfect and knock down gene expression in cells bearing the surface receptor recognized by the aptamer. The PSMA aptamer-siRNA chimeras targeting PSMA silenced target gene expression in prostate cancer mouse xenografts [96]. AsiCs containing an aptamer targeting HIV-gp120 inhibit HIV replication in already infected cells in vitro $[119,120]$ and in vivo [121]. CD4-AsiCs bearing siRNAs that recognized HIV gag and vif or host CCR5 were specifically taken up by $\mathrm{CD} 4^{+}$ cells, knocked down genes expression, and inhibited HIV infection in primary $\mathrm{CD} 4^{+} \mathrm{T}$ cells and in the female genital tract of humanized mice $[122,123]$ and at the same time do not activate lymphocytes or stimulate innate immunity $[122,123]$. Moreover, the chimeras do not bind to or function in cells that do not express CD4, such as CD3, CD8, and CD45 [124]. Thus, aptamer-facilitated cell specific delivery of siRNA/shRNA represents an attractive novel approach 


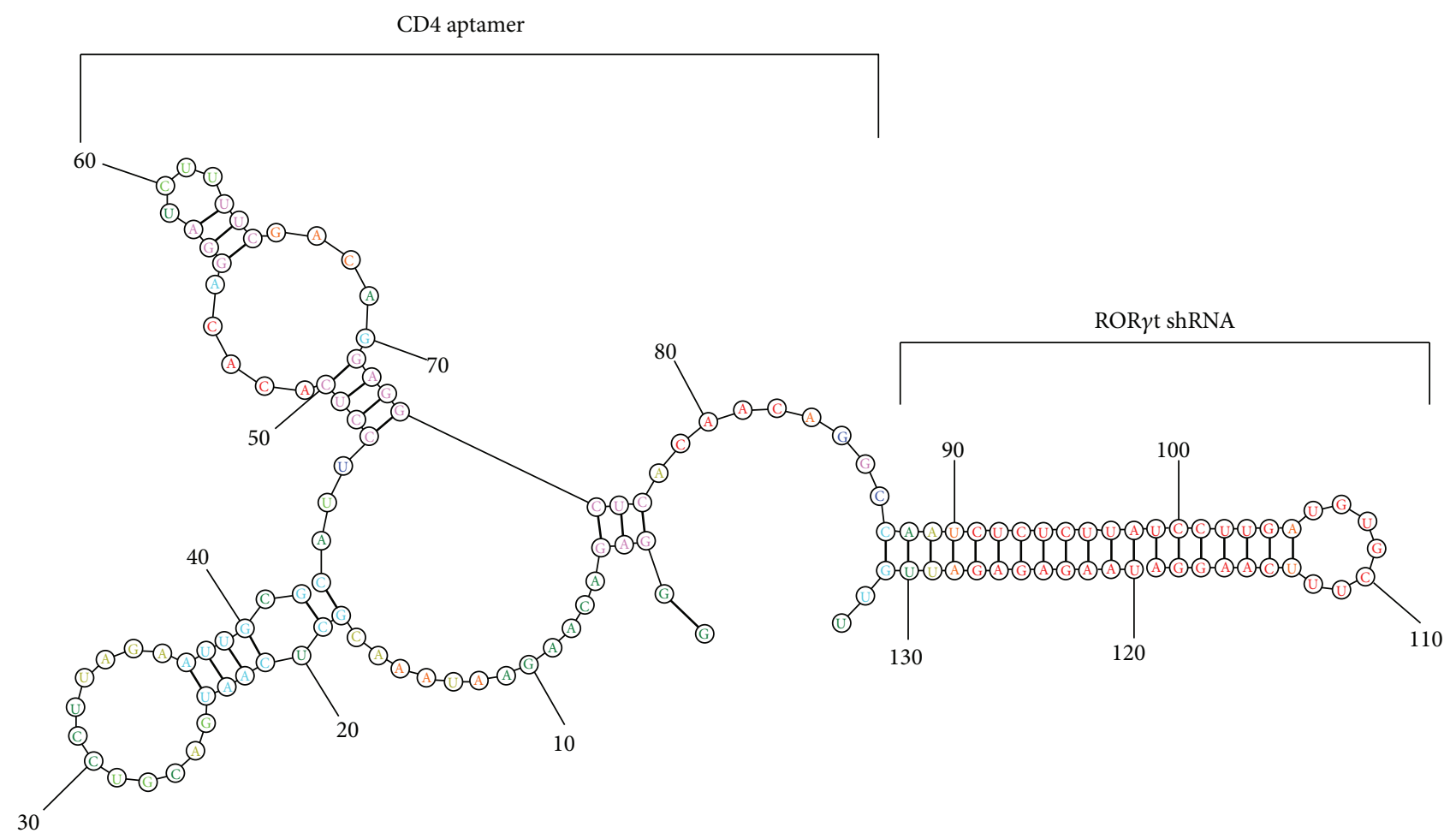

FIGURE 1: Predicted secondary structure of CD4-aptamer-ROR $\gamma$ t shRNA chimera (modified from Song et al., BBRC, 2014, Figure 1(b) [104] with permission).

for efficient RNAi delivery. CD4-AsiCs overcome the hurdle of in vivo siRNA delivery to the immune cells and hold a promise to study immune responses and develop therapeutics in autoimmune diseases.

5.3. CD4 Aptamer-ROR $\gamma t$ shRNA Chimeras. CD4 aptamers that bind surface CD4 can be applied as T helper cellspecific delivering vehicles. CD4-AsiCs bearing siRNAs or shRNA targeting ROR $\gamma t$ might suppress Th17 differentiation and treat Th17-mediated autoimmune diseases. We selected CD4 RNA aptamers (86 nucleotides in length) that delivered ROR $\gamma$ t-shRNA (Figure 1) into $\mathrm{CD} 4^{+} \mathrm{T}$ cells and investigated its efficacy in suppressing Th17 cell differentiation and IL-17 production in human $\mathrm{CD} 4^{+} \mathrm{T}$ cells in vitro [104]. Chemical modifications of nucleotides $2^{\prime}-F-d C T P$ and $2^{\prime}-F-d U T P$ were done to enhance the nuclease resistance of the aptamer chimeras [104]. In vitro using fluorescent microscope and flow cytometric analysis, Cy3-labeled CD4 aptamer-ROR $\gamma \mathrm{t}$ shRNA chimeras (CD4-AshR-ROR $\gamma \mathrm{t}$ ) (133 nucleotides in length) were shown to enter into human $\mathrm{CD}^{+} \mathrm{T}$ cells but not Cy3-labeled mock CD4-AshR- ROR $\gamma$ t. In vitro expression of ROR $\gamma \mathrm{t}$ is significantly and specifically diminished by CD4-AshR-ROR $\gamma \mathrm{t}$ in a concentration-dependent manner in human $\mathrm{CD} 4^{+} \mathrm{T}$ cells compared with control CD4 aptamers [104]. Consistent with decreased ROR $\gamma \mathrm{t}, \mathrm{CD} 4-\mathrm{AshR}-\mathrm{ROR} \gamma \mathrm{t}$ displayed a concentration-dependent inhibition of IL-17A release from $\mathrm{CD}^{+} \mathrm{T}$ cells and intracellular IL-17A staining in $\mathrm{CD}^{+}{ }^{+} \mathrm{T}$ cells, while mock CD4-AshR-ROR $\gamma \mathrm{t}$ and CD4AshR-scrambled control have no impacts [104]. This study indicates that intracellular delivery of CD4-AshR-ROR $\gamma \mathrm{t}$ could target ROR $\gamma \mathrm{t}$ and manipulate Thl7 cell differentiation and IL-17 production in $\mathrm{CD} 4^{+} \mathrm{T}$ cells. Additionally, CD4AshR-ROR $\gamma$ t does not significantly impact the expression of Th1 and Th2 lineage transcription factors T-bet and GATA-3 in PMBCs. Consistent with these, synthesis of IFN- $\gamma$ and IL-4 in PBMCs is not changed by CD4-AshR-ROR $\gamma \mathrm{t}$.

These suggest that CD4-AshR-ROR $\gamma$ t chimeras keep its specificity to target ROR $y$ t gene and Th17 cells. Thus, it is of interest to explore the use of CD4-AshR-ROR $\gamma t$ chimeras in animal and clinical trials of autoimmune diseases.

\section{Concluding Remarks}

In conclusion, Th17 cells and their signature cytokines play crucial roles in the pathology of autoimmune and inflammatory diseases. Targeting IL-17 or IL-17R has shown clinical efficacy in psoriasis but not many other autoimmune disease such as RA and Crohn's disease. In contrast to blocking a single effector cytokine, targeting Th17 lineage provides promising therapeutic to impact multiple inflammatory cytokines. First attempts to target Th17 lineage are targeting ROR $\gamma \mathrm{t}$, the master transcriptional factor of Th17 lineage, via small molecule inverse agonists. Several small molecules are shown to have potent suppressive effects on Th17 cells and their cytokines and have therapeutic efficacy in animal models of autoimmune diseases. Clinical studies are required to assess their usefulness for treating Th17-mediated human diseases. Aptamer mediated delivery of siRNA/shRNA specifically 
against ROR $\gamma$ t offers another strategy to target Th17 cells. By replacing the shRNA for targeted genes such as GATA3, Tbet, and STAT3; this CD4 aptamer may be used as a universal tool to introduce siRNA or shRNA into $\mathrm{CD}^{+} \mathrm{T}$ cells to manipulate function of various Th cells. Further animal and clinical trials of CD4-AshR-ROR $\gamma$ t chimeras are necessary to evaluate the beneficial outcomes in autoimmune diseases.

\section{Conflict of Interests}

Cong-Qiu Chu has filed a patent application "Aptamer-RNAi Therapeutic Compositions." Other authors declare that there is no conflict of interests regarding the publication of this paper.

\section{Acknowledgments}

This work was supported by Grant no. 81102274 from the National Natural Science Foundation of China; Grant no. 10GGYB644SF-023 from Science and Technology Foundation of Chengdu (Hui Lin); $2014 \mathrm{HH} 0027$ from Science and Technology Foundation of International Cooperation of Sichuan Province (Yi Liu); NIH (AR55254); Rheumatology Research Foundation and National Psoriasis Foundation (Cong-Qiu Chu).

\section{References}

[1] T. R. Mosmann, H. Cherwinski, M. W. Bond, M. A. Giedlin, and R. L. Coffman, "Two types of murine helper T cell clone. I. Definition according to profiles of lymphokine activities and secreted proteins," The Journal of Immunology, vol. 136, no. 7, pp. 2348-2357, 1986.

[2] D. Agnello, C. S. R. Lankford, J. Bream et al., "Cytokines and transcription factors that regulate $\mathrm{T}$ helper cell differentiation: new players and new insights," Journal of Clinical Immunology, vol. 23, no. 3, pp. 147-161, 2003.

[3] K. A. Mowen and L. H. Glimcher, "Signaling pathways in Th2 development," Immunological Reviews, vol. 202, pp. 203-222, 2004.

[4] M. Veldhoen, C. Uyttenhove, J. van Snick et al., “Transforming growth factor- $\beta$ 'reprograms' the differentiation of T helper 2 cells and promotes an interleukin 9-producing subset," Nature Immunology, vol. 9, no. 12, pp. 1341-1346, 2008.

[5] D. Breitfeld, L. Ohl, E. Kremmer et al., "Follicular B helper $\mathrm{T}$ cells express CXC chemokine receptor 5, localize to B cell follicles, and support immunoglobulin production," Journal of Experimental Medicine, vol. 192, no. 11, pp. 1545-1551, 2000.

[6] S. Sakaguchi, T. Yamaguchi, T. Nomura, and M. Ono, "Regulatory T cells and immune tolerance," Cell, vol. 133, no. 5, pp. 775-787, 2008.

[7] H. Park, Z. Li, X. O. Yang et al., "A distinct lineage of CD4 T cells regulates tissue inflammation by producing interleukin 17," Nature Immunology, vol. 6, no. 11, pp. 1133-1141, 2005.

[8] L. E. Harrington, R. D. Hatton, P. R. Mangan et al., "Interleukin 17-producing $\mathrm{CD}^{+}$effector $\mathrm{T}$ cells develop via a lineage distinct from the T helper type 1 and 2 lineages," Nature Immunology, vol. 6, no. 11, pp. 1123-1132, 2005.

[9] I. I. Ivanov, B. S. McKenzie, L. Zhou et al., "The orphan nuclear receptor RORgammat directs the differentiation program of proinflammatory IL-17+ T helper cells," Cell, vol. 126, no. 6, pp. 1121-1133, 2006.

[10] C. Dong, “TH17 cells in development: an updated view of their molecular identity and genetic programming," Nature Reviews Immunology, vol. 8, no. 5, pp. 337-348, 2008.

[11] F. Annunziato, L. Cosmi, F. Liotta, E. Maggi, and S. Romagnani, "Type $17 \mathrm{~T}$ helper cells-origins, features and possible roles in rheumatic disease," Nature Reviews Rheumatology, vol. 5, no. 6, pp. 325-331, 2009.

[12] L. Steinman, "Mixed results with modulation of T H-17 cells in human autoimmune diseases," Nature Immunology, vol. 11, no. 1, pp. 41-44, 2010.

[13] W. Hueber, D. D. Patel, T. Dryja et al., "Effects of AIN457, a fully human antibody to interleukin-17A, on psoriasis, rheumatoid arthritis, and uveitis," Science Translational Medicine, vol. 2, no. 52, Article ID 52ra72, 2010.

[14] C. Leonardi, R. Matheson, C. Zachariae et al., "Anti-interleukin17 monoclonal antibody ixekizumab in chronic plaque psoriasis," The New England Journal of Medicine, vol. 366, no. 13, pp. 1190-1191, 2012.

[15] P. Gisondi, C. Dalle Vedove, and G. Girolomoni, "Efficacy and safety of secukinumab in chronic plaque psoriasis and psoriatic arthritis therapy," Dermatology and Therapy, vol. 4, no. 1, pp. 1-9, 2014.

[16] D. D. Patel, D. M. Lee, F. Kolbinger, and C. Antoni, "Effect of IL-17A blockade with secukinumab in autoimmune diseases," Annals of the Rheumatic Diseases, vol. 72, supplement 2, pp. iil16-iil23, 2013.

[17] K. A. Papp, C. Leonardi, A. Menter et al., "Brodalumab, an anti-interleukin-17-receptor antibody for psoriasis," The New England Journal of Medicine, vol. 366, no. 13, pp. 1181-1189, 2012.

[18] S. Coimbra, A. Figueiredo, and A. Santos-Silva, "Brodalumab: an evidence-based review of its potential in the treatment of moderate-to-severe psoriasis," Core Evidence, vol. 9, pp. 89-97, 2014.

[19] D. A. Martin, M. Churchill, L. F. Flores-Suarez et al., "A phase Ib multiple ascending dose study evaluating safety, pharmacokinetics, and early clinical response of brodalumab, a human anti-IL-17R antibody, in methotrexate-resistant rheumatoid arthritis," Arthritis Research and Therapy, vol. 15, no. 5, article R164, 2013.

[20] M. C. Genovese, P. Durez, H. B. Richards et al., "Efficacy and safety of secukinumab in patients with rheumatoid arthritis: a phase II, dose-finding, double-blind, randomised, placebo controlled study," Annals of the Rheumatic Diseases, vol. 72, no. 6, pp. 863-869, 2013.

[21] W. Hueber, B. E. Sands, S. Lewitzky et al., "Secukinumab, a human anti-IL-17A monoclonal antibody, for moderate to severe Crohn's disease: unexpected results of a randomised, double-blind placebo-controlled trial," Gut, vol. 61, no. 12, pp. 1693-1700, 2012.

[22] J. Yang, M. S. Sundrud, J. Skepner, and T. Yamagata, “Targeting Th17 cells in autoimmune diseases," Trends in Pharmacological Sciences, vol. 35, no. 10, pp. 493-500, 2014.

[23] T. Korn, E. Bettelli, M. Oukka, and V. K. Kuchroo, "IL-17 and Th17 cells," Annual Review of Immunology, vol. 27, pp. 485-517, 2009.

[24] E. H. Tran, E. N. Prince, and T. Owens, "IFN- $\gamma$ shapes immune invasion of the central nervous system via regulation of chemokines," The Journal of Immunology, vol. 164, no. 5, pp. 2759-2768, 2000. 
[25] B. Gran, G.-X. Zhang, S. Yu et al., "IL-12p35-deficient mice are susceptible to experimental autoimmune encephalomyelitis: evidence for redundancy in the IL-12 system in the induction of central nervous system autoimmune demyelination," Journal of Immunology, vol. 169, no. 12, pp. 7104-7110, 2002.

[26] C.-Q. Chu, Z. Song, L. Mayton, B. Wu, and P. H. Wooley, "IFNgamma deficient C57BL/6 (H-2b) mice develop collagen induced arthritis with predominant usage of $\mathrm{T}$ cell receptor Vbeta6 and Vbeta8 in arthritic joints," Annals of the Rheumatic Diseases, vol. 62, no. 10, pp. 983-990, 2003.

[27] C.-Q. Chu, S. Wittmer, and D. K. Dalton, "Failure to suppress the expansion of the activated CD4 $\mathrm{T}$ cell population in interferon $\gamma$-deficient mice leads to exacerbation of experimental autoimnaune encephalomyelitis," The Journal of Experimental Medicine, vol. 192, no. 1, pp. 123-128, 2000.

[28] B. Oppmann, R. Lesley, B. Blom et al., "Novel p19 protein engages IL-12p40 to form a cytokine, IL-23, with biological activities similar as well as distinct from IL-12," Immunity, vol. 13, no. 5, pp. 715-725, 2000.

[29] D. J. Cua, J. Sherlock, Y. Chen et al., "Interleukin-23 rather than interleukin-12 is the critical cytokine for autoimmune inflammation of the brain," Nature, vol. 421, no. 6924, pp. 744748, 2003.

[30] C. L. Langrish, Y. Chen, W. M. Blumenschein et al., "IL-23 drives a pathogenic $\mathrm{T}$ cell population that induces autoimmune inflammation," Journal of Experimental Medicine, vol. 201, no. 2, pp. 233-240, 2005.

[31] M. O. Li, Y. Y. Wan, S. Sanjabi, A.-K. L. Robertson, and R. A. Flavell, "Transforming growth factor- $\beta$ regulation of immune responses," Annual Review of Immunology, vol. 24, pp. 99-146, 2006.

[32] M. Veldhoen, R. J. Hocking, R. A. Flavell, and B. Stockinger, "Signals mediated by transforming growth factor- $\beta$ initiate autoimmune encephalomyelitis, but chronic inflammation is needed to sustain disease," Nature Immunology, vol. 7, no. 11, pp. 1151-1156, 2006.

[33] E. Bettelli, Y. Carrier, W. Gao et al., "Reciprocal developmental pathways for the generation of pathogenic effector TH17 and regulatory T cells," Nature, vol. 441, no. 7090, pp. 235-238, 2006.

[34] P. R. Mangan, L. E. Harrington, D. B. O'Quinn et al., “Transforming growth factor- $\beta$ induces development of the $\mathrm{T}_{\mathrm{H}} 17$ lineage," Nature, vol. 441, no. 7090, pp. 231-234, 2006.

[35] R. Nurieva, X. O. Yang, G. Martinez et al., "Essential autocrine regulation by IL-21 in the generation of inflammatory T cells," Nature, vol. 448, no. 7152, pp. 480-483, 2007.

[36] L. Zhou, I. I. Ivanov, R. Spolski et al., "IL-6 programs TH-17 cell differentiation by promoting sequential engagement of the IL21 and IL-23 pathways," Nature Immunology, vol. 8, no. 9, pp. 967-974, 2007.

[37] T. Korn, E. Bettelli, W. Gao et al., "IL-21 initiates an alternative pathway to induce proinflammatory $\mathrm{T}_{\mathrm{H}} 17$ cells," Nature, vol. 448, no. 7152, pp. 484-487, 2007.

[38] J. M. Coquet, S. Chakravarti, M. J. Smyth, and D. I. Godfrey, "Cutting edge: IL-21 is not essential for Th17 differentiation or experimental autoimmune encephalomyelitis," Journal of Immunology, vol. 180, no. 11, pp. 7097-7101, 2008.

[39] R. Liu, Y. Bai, T. L. Vollmer et al., "IL-21 Receptor expression determines the temporal phases of experimental autoimmune encephalomyelitis," Experimental Neurology, vol. 211, no. 1, pp. 14-24, 2008.
[40] K. Hirota, B. Martin, and M. Veldhoen, "Development, regulation and functional capacities of Th17 cells," Seminars in Immunopathology, vol. 32, no. 1, pp. 3-16, 2010.

[41] M. J. McGeachy, K. S. Bak-Jensen, Y. Chen et al., “TGF-beta and IL- 6 drive the production of IL-17 and IL-10 by T cells and restrain T(H)-17 cell-mediated pathology," Nature Immunology, vol. 8, pp. 1390-1397, 2007.

[42] Y. Chen, C. L. Langrish, B. Mckenzie et al., "Anti-IL-23 therapy inhibits multiple inflammatory pathways and ameliorates autoimmune encephalomyelitis," The Journal of Clinical Investigation, vol. 116, no. 5, pp. 1317-1326, 2006.

[43] C. L. Leonardi, A. B. Kimball, K. A. Papp et al., "Efficacy and safety of ustekinumab, a human interleukin-12/23 monoclonal antibody, in patients with psoriasis: 76-week results from a randomised, double-blind, placebo-controlled trial (PHOENIX 1)," The Lancet, vol. 371, no. 9625, pp. 1665-1674, 2008.

[44] W. J. Sandborn, C. Gasink, L.-L. Gao et al., "Ustekinumab induction and maintenance therapy in refractory Crohn's disease," The New England Journal of Medicine, vol. 367, no. 16, pp. 15191528, 2012.

[45] E. V. Acosta-Rodriguez, G. Napolitani, A. Lanzavecchia, and F. Sallusto, "Interleukins 1beta and 6 but not transforming growth factor-beta are essential for the differentiation of interleukin 17producing human Thelper cells," Nature Immunology, vol. 8, no. 9, pp. 942-949, 2007.

[46] N. J. Wilson, K. Boniface, J. R. Chan et al., "Development, cytokine profile and function of human interleukin 17producing helper T cells," Nature Immunology, vol. 8, no. 9, pp. 950-957, 2007.

[47] K. Hirahara, K. Ghoreschi, A. Laurence, X.-P. Yang, Y. Kanno, and J. J. O'Shea, "Signal transduction pathways and transcriptional regulation in Th17 cell differentiation," Cytokine and Growth Factor Reviews, vol. 21, no. 6, pp. 425-434, 2010.

[48] A. M. Jetten, "Retinoid-related orphan receptors (RORs): critical roles in development, immunity, circadian rhythm, and cellular metabolism," Nuclear Receptor Signaling, vol. 7, article e003, 2009.

[49] Y.-W. He, M. L. Deftos, E. W. Ojala, and M. J. Bevan, "ROR $\gamma$ t, a novel isoform of an orphan receptor, negatively regulates Fas ligand expression and IL-2 production in T cells," Immunity, vol. 9, no. 6, pp. 797-806, 1998.

[50] G. Eberl and D. R. Littman, "The role of the nuclear hormone receptor ROR $\gamma \mathrm{t}$ in the development of lymph nodes and Peyer's patches," Immunological Reviews, vol. 195, pp. 81-90, 2003.

[51] G. Eberl, S. Marmon, M.-J. Sunshine, P. D. Rennert, Y. Choi, and D. R. Littmann, "An essential function for the nuclear receptor ROR $\gamma \mathrm{t}$ in the generation of fetal lymphoid tissue inducer cells," Nature Immunology, vol. 5, no. 1, pp. 64-73, 2004.

[52] S. Kurebayashi, E. Ueda, M. Sakaue et al., "Retinoid-related orphan receptor $\gamma(\operatorname{ROR} \gamma)$ is essential for lymphoid organogenesis and controls apoptosis during thymopoiesis," Proceedings of the National Academy of Sciences of the United States of America, vol. 97, no. 18, pp. 10132-10137, 2000.

[53] Z. Sun, D. Unutmaz, Y.-R. Zou et al., "Requirement for ROR $\gamma$ in thymocyte survival and lymphoid organ development," Science, vol. 288, no. 5475, pp. 2369-2373, 2000.

[54] N. Manel, D. Unutmaz, and D. R. Littman, "The differentiation of human TH-17 cells requires transforming growth factor- $\beta$ and induction of the nuclear receptor ROR $\gamma \mathrm{t}$," Nature Immunology, vol. 9, no. 6, pp. 641-649, 2008. 
[55] I. I. Ivanov, L. Zhou, and D. R. Littman, "Transcriptional regulation of Th17 cell differentiation," Seminars in Immunology, vol. 19, no. 6, pp. 409-417, 2007.

[56] C. Q. Chu, A. Mello, P. Gulko, and K. B. Elkon, "ROR $\gamma$ t overexpression predisposes to increased susceptibility and severity of experimental arthritis," Arthritis \& Rheumatism, vol. 58, p. S936, 2008.

[57] X. O. Yang, B. P. Pappu, R. Nurieva et al., “T helper 17 lineage differentiation is programmed by orphan nuclear receptors ROR $\alpha$ and ROR $\gamma$," Immunity, vol. 28, no. 1, pp. 29-39, 2008.

[58] X. O. Yang, A. D. Panopoulos, R. Nurieva et al., "STAT3 regulates cytokine-mediated generation of inflammatory helper T cells," The Journal of Biological Chemistry, vol. 282, no. 13, pp. 9358-9363, 2007.

[59] A. N. Mathur, H.-C. Chang, D. G. Zisoulis et al., "Stat3 and Stat4 direct development of IL-17-secreting Th cells," The Journal of Immunology, vol. 178, no. 8, pp. 4901-4907, 2007.

[60] T. J. Harris, J. F. Grosso, H.-R. Yen et al., "Cutting edge: an in vivo requirement for STAT3 signaling in TH17 development and TH17-dependent autoimmunity," Journal of Immunology, vol. 179, no. 7, pp. 4313-4317, 2007.

[61] L. Wei, A. Laurence, K. M. Elias, and J. J. O’Shea, "IL-21 is produced by Th17 cells and drives IL-17 production in a STAT3dependent manner," The Journal of Biological Chemistry, vol. 282, no. 48, pp. 34605-34610, 2007.

[62] Z. Chen, A. Laurence, Y. Kanno et al., "Selective regulatory function of Socs3 in the formation of IL-17-secreting T cells," Proceedings of the National Academy of Sciences of the United States of America, vol. 103, no. 21, pp. 8137-8142, 2006.

[63] M. Lohoff, H.-W. Mittrücker, S. Prechtl et al., "Dysregulated T helper cell differentiation in the absence of interferon regulatory factor 4," Proceedings of the National Academy of Sciences of the United States of America, vol. 99, no. 18, pp. 11808-11812, 2002.

[64] P. S. Biswas, S. Gupta, E. Chang et al., "Phosphorylation of IRF4 by ROCK 2 regulates IL-17 and IL-21 production and the development of autoimmunity in mice," The Journal of Clinical Investigation, vol. 120, no. 9, pp. 3280-3295, 2010.

[65] A. Brüstle, S. Heink, M. Huber et al., "The development of inflammatory $\mathrm{T}_{\mathrm{H}}-17$ cells requires interferon-regulatory factor 4," Nature Immunology, vol. 8, no. 9, pp. 958-966, 2007.

[66] B. U. Schraml, K. Hildner, W. Ise et al., "The AP-1 transcription factor Batf controls T H 17 differentiation," Nature, vol. 460, no. 7253, pp. 405-409, 2009.

[67] F. Zhang, G. Meng, and W. Strober, "Interactions among the transcription factors Runxl, ROR $\gamma \mathrm{t}$ and Foxp3 regulate the differentiation of interleukin 17-producing T cells," Nature Immunology, vol. 9, no. 11, pp. 1297-1306, 2008.

[68] J. R. Huh, M. W. L. Leung, P. Huang et al., "Digoxin and its derivatives suppress $\mathrm{T}_{\mathrm{H}} 17$ cell differentiation by antagonizing ROR $\gamma$ t activity," Nature, vol. 472, no. 7344, pp. 486-490, 2011.

[69] S. Fujita-Sato, S. Ito, T. Isobe et al., "Structural basis of digoxin that antagonizes ROR $\gamma$ t receptor activity and suppresses Th17 cell differentiation and interleukin (IL)-17 production," The Journal of Biological Chemistry, vol. 286, no. 36, pp. 31409-31417, 2011.

[70] R. Cascão, B. Vidal, H. Raquel et al., "Effective treatment of rat adjuvant-induced arthritis by celastrol," Autoimmunity Reviews, vol. 11, no. 12, pp. 856-862, 2012.

[71] J. R. Huh, E. E. Englund, H. Wang et al., "Identification of potent and selective diphenylpropanamide ROR $\gamma$ inhibitors," ACS Medicinal Chemistry Letters, vol. 4, no. 1, pp. 79-84, 2013.
[72] N. Kumar, L. A. Solt, J. J. Conkright et al., "The benzenesulfoamide T0901317 [N-(2,2,2-trifluoroethyl)-N[4-[2,2,2-trifluoro-1-hydroxy-1-(trifluoromethyl)ethyl]phenyl]benzenesulfonamide] is a novel retinoic acid receptor-related orphan receptor-alpha/gamma inverse agonist," Molecular Pharmacology, vol. 77, no. 2, pp. 228-236, 2010.

[73] L. A. Solt, N. Kumar, P. Nuhant et al., "Suppression of $\mathrm{T}_{\mathrm{H}} 17$ differentiation and autoimmunity by a synthetic ROR ligand," Nature, vol. 472, no. 7344, pp. 491-494, 2011.

[74] N. Kumar, B. Lyda, M. R. Chang et al., "Identification of SR2211: a potent synthetic ROR $\gamma$-selective modulator," ACS Chemical Biology, vol. 7, no. 4, pp. 672-677, 2012.

[75] M. R. Chang, B. Lyda, T. M. Kamenecka, and P. R. Griffin, "Pharmacologic repression of retinoic acid receptor-related orphan nuclear receptor gamma is therapeutic in the collagen-induced arthritis experimental model," Arthritis and Rheumatology, vol. 66, no. 3, pp. 579-588, 2014.

[76] T. Xu, X. Wang, B. Zhong, R. I. Nurieva, S. Ding, and C. Dong, "Ursolic acid suppresses interleukin-17 (IL-17) production by selectively antagonizing the function of ROR $\gamma \mathrm{t}$ protein," The Journal of Biological Chemistry, vol. 286, no. 26, pp. 2270722710, 2011.

[77] S. Xiao, N. Yosef, J. Yang et al., "Small-molecule ROR $\gamma t$ antagonists inhibit $\mathrm{T}$ helper 17 cell transcriptional network by divergent mechanisms," Immunity, vol. 40, no. 4, pp. 477-489, 2014.

[78] J. Skepner, R. Ramesh, M. Trocha et al., "Pharmacologic inhibition of ROR $\gamma \mathrm{t}$ regulates Th17 signature gene expression and suppresses cutaneous inflammation in vivo," The Journal of Immunology, vol. 192, no. 6, pp. 2564-2575, 2014.

[79] J. R. Huh and D. R. Littman, "Small molecule inhibitors of ROR $\gamma$ t: targeting Th17 cells and other applications," European Journal of Immunology, vol. 42, no. 9, pp. 2232-2237, 2012.

[80] M. Freeley and A. Long, "Advances in siRNA delivery to T-cells: potential clinical applications for inflammatory disease, cancer and infection," Biochemical Journal, vol. 455, no. 2, pp. 133-147, 2013.

[81] A. D. Ellington and J. W. Szostak, "In vitro selection of RNA molecules that bind specific ligands," Nature, vol. 346, no. 6287, pp. 818-822, 1990.

[82] S. Shigdar, C. Qian, L. Lv et al., “The use of sensitive chemical antibodies for diagnosis: detection of low levels of EpCAM in breast cancer," PLoS ONE, vol. 8, no. 2, Article ID e57613, 2013.

[83] L. Cerchia and V. de Franciscis, "Targeting cancer cells with nucleic acid aptamers," Trends in Biotechnology, vol. 28, no. 10, pp. 517-525, 2010.

[84] A. D. Keefe and J. W. Szostak, "Functional proteins from a random-sequence library," Nature, vol. 410, no. 6829, pp. 715718, 2001.

[85] R. Stoltenburg, C. Reinemann, and B. Strehlitz, "SELEX-A (r)evolutionary method to generate high-affinity nucleic acid ligands," Biomolecular Engineering, vol. 24, no. 4, pp. 381-403, 2007.

[86] S. M. Shamah, J. M. Healy, and S. T. Cload, "Complex target SELEX," Accounts of Chemical Research, vol. 41, no. 1, pp. 130138, 2008.

[87] K.-T. Guo, A. Paul, C. Schichor, G. Ziemer, and H. P. Wendel, "Cell-SELEX: novel perspectives of aptamer-based therapeutics," International Journal of Molecular Sciences, vol. 9, no. 4, pp. 668-678, 2008. 
[88] K. Sefah, Z. W. Tang, D. H. Shangguan et al., "Molecular recognition of acute myeloid leukemia using aptamers," Leukemia, vol. 23, no. 2, pp. 235-244, 2009.

[89] D. Xiang, S. Shigdar, G. Qiao et al., "Nucleic acid aptamerguided cancer therapeutics and diagnostics: the next generation of cancer medicine," Theranostics, vol. 5, no. 1, pp. 23-42, 2015.

[90] J. Zhou and J. J. Rossi, "Cell-type-specific, aptamerfunctionalized agents for targeted disease therapy," Molecular Therapy Nucleic Acids, vol. 3, article e169, 2014.

[91] S. Shigdar, J. Macdonald, M. O'Connor et al., "Aptamers as theranostic agents: modifications, serum stability and functionalisation," Sensors, vol. 13, no. 10, pp. 13624-13637, 2013.

[92] A. D. Keefe, S. Pai, and A. Ellington, "Aptamers as therapeutics," Nature Reviews Drug Discovery, vol. 9, no. 7, pp. 537-550, 2010.

[93] J. G. Bruno, "A review of therapeutic aptamer conjugates with emphasis on new approaches," Pharmaceuticals, vol. 6, no. 3, pp. 340-357, 2013.

[94] L. Meng, L. Yang, X. Zhao et al., "Targeted delivery of chemotherapy agents using a liver cancer-specific aptamer," PloS ONE, vol. 7, no. 4, Article ID e33434, 2012.

[95] P. R. Bouchard, R. M. Hutabarat, and K. M. Thompson, "Discovery and development of therapeutic aptamers," Annual Review of Pharmacology and Toxicology, vol. 50, pp. 237-257, 2010.

[96] J. P. Dassie, X.-Y. Liu, G. S. Thomas et al., "Systemic administration of optimized aptamer-siRNA chimeras promotes regression of PSMA-expressing tumors," Nature Biotechnology, vol. 27, no. 9, pp. 839-846, 2009.

[97] F. A. Harding, M. M. Stickler, J. Razo, and R. B. DuBridge, "The immunogenicity of humanized and fully human antibodies: residual immunogenicity resides in the CDR regions," $m A b s$, vol. 2, no. 3, pp. 256-265, 2010.

[98] L. Hedden, S. O’Reilly, C. Lohrisch et al., "Assessing the realworld cost-effectiveness of adjuvant trastuzumab in HER-2/neu positive breast cancer," Oncologist, vol. 17, no. 2, pp. 164-171, 2012.

[99] S. D. Jayasena, "Aptamers: an emerging class of molecules that rival antibodies in diagnostics," Clinical Chemistry, vol. 45, no. 9, pp. 1628-1650, 1999.

[100] E. W. M. Ng and A. P. Adamis, "Anti-VEGF aptamer (pegaptanib) therapy for ocular vascular diseases," Annals of the New York Academy of Sciences, vol. 1082, pp. 151-171, 2006.

[101] J. C. Burnett and J. J. Rossi, "RNA-based therapeutics: current progress and future prospects," Chemistry and Biology, vol. 19, no. 1 , pp. $60-71,2012$.

[102] P. Sundaram, H. Kurniawan, M. E. Byrne, and J. Wower, "Therapeutic RNA aptamers in clinical trials," European Journal of Pharmaceutical Sciences, vol. 48, no. 1-2, pp. 259-271, 2013.

[103] S. M. Nimjee, C. P. Rusconi, and B. A. Sullenger, "Aptamers: an emerging class of therapeutics," Annual Review of Medicine, vol. 56, pp. 555-583, 2005.

[104] P. Song, Y. K. Chou, X. Zhang et al., "CD4 aptamer-ROR $\gamma \mathrm{t}$ shRNA chimera inhibits IL-17 synthesis by human $\mathrm{CD}^{+} \mathrm{T}$ cells," Biochemical and Biophysical Research Communications, vol. 452, no. 4, pp. 1040-1045, 2014.

[105] A. Fire, S. Xu, M. K. Montgomery, S. A. Kostas, S. E. Driver, and C. C. Mello, "Potent and specific genetic interference by doublestranded RNA in caenorhabditis elegans," Nature, vol. 391, no. 6669, pp. 806-811, 1998.

[106] S. M. Elbashir, J. Harborth, W. Lendeckel, A. Yalcin, K. Weber, and T. Tuschl, "Duplexes of 21-nucleotide RNAs mediate RNA interference in cultured mammalian cells," Nature, vol. 411, no. 6836, pp. 494-498, 2001.

[107] D. Bumcrot, M. Manoharan, V. Koteliansky, and D. W. Y. Sah, "RNAi therapeutics: a potential new class of pharmaceutical drugs," Nature Chemical Biology, vol. 2, no. 12, pp. 711-719, 2006.

[108] J. Gehl, "Electroporation: theory and methods, perspectives for drug delivery, gene therapy and research," Acta Physiologica Scandinavica, vol. 177, no. 4, pp. 437-447, 2003.

[109] W. Lai, C.-H. Chang, and D. L. Farber, "Gene transfection and expression in resting and activated murine CD4 T cell subsets," Journal of Immunological Methods, vol. 282, no. 1-2, pp. 93-102, 2003.

[110] A. G. Gómez-Valadés, M. Llamas, S. Blanch et al., "Specific Jak3 downregulation in lymphocytes impairs $\gamma$ c cytokine signal transduction and alleviates antigen-driven inflammation in vivo," Molecular Therapy -Nucleic Acids, vol. 1, article e42, 2012.

[111] M. Rangachari, C. Zhu, K. Sakuishi et al., "Bat3 promotes T cell responses and autoimmunity by repressing Tim-3-mediated cell death and exhaustion," Nature Medicine, vol. 18, no. 9, pp. 13941400, 2012.

[112] H.-S. Jin, L. Liao, Y. Park, and Y.-C. Liu, "Neddylation pathway regulates $\mathrm{T}$-cell function by targeting an adaptor protein Shc and a protein kinase Erk signaling," Proceedings of the National Academy of Sciences of the United States of America, vol. 110, no. 2, pp. 624-629, 2013.

[113] Z. Liu, M. Winters, M. Holodniy, and H. Dai, "siRNA delivery into human $\mathrm{T}$ cells and primary cells with carbon-nanotube transporters," Angewandte Chemie-International Edition, vol. 46, no. 12, pp. 2023-2027, 2007.

[114] E. Song, P. Zhu, S.-K. Lee et al., "Antibody mediated in vivo delivery of small interfering RNAs via cell-surface receptors," Nature Biotechnology, vol. 23, no. 6, pp. 709-717, 2005.

[115] D. Peer, P. Zhu, C. V. Carman, J. Lieberman, and M. Shimaoka, "Selective gene silencing in activated leukocytes by targeting siRNAs to the integrin lymphocyte function-associated antigen-1," Proceedings of the National Academy of Sciences of the United States of America, vol. 104, no. 10, pp. 4095-4100, 2007.

[116] P. Kumar, H.-S. Ban, S.-S. Kim et al., "T cell-specific siRNA delivery suppresses HIV-1 infection in humanized mice," Cell, vol. 134, no. 4, pp. 577-586, 2008.

[117] S. Shigdar, A. C. Ward, A. De, C. J. Yang, M. Wei, and W. Duan, "Clinical applications of aptamers and nucleic acid therapeutics in haematological malignancies," British Journal of Haematology, vol. 155, no. 1, pp. 3-13, 2011.

[118] J. O. McNamara II, E. R. Andrechek, Y. Wang et al., "Cell typespecific delivery of siRNAs with aptamer-siRNA chimeras," Nature Biotechnology, vol. 24, no. 8, pp. 1005-1015, 2006.

[119] J. Zhou, H. Li, S. Li, J. Zaia, and J. J. Rossi, "Novel dual inhibitory function aptamer-siRNA delivery system for HIV-1 therapy," Molecular Therapy, vol. 16, no. 8, pp. 1481-1489, 2008.

[120] J. Zhou, P. Swiderski, H. Li et al., "Selection, characterization and application of new RNA HIV gp 120 aptamers for facile delivery of Dicer substrate siRNAs into HIV infected cells," Nucleic Acids Research, vol. 37, no. 9, pp. 3094-3109, 2009.

[121] C. P. Neff, J. Zhou, L. Remling et al., "An aptamer-siRNA chimera suppresses HIV-1 viral loads and protects from helper $\mathrm{CD}^{+} \mathrm{T}$ cell decline in humanized mice," Science Translational Medicine, vol. 3, no. 66, Article ID 66ra6, 2011.

[122] L. A. Wheeler, R. Trifonova, V. Vrbanac et al., "Inhibition of HIV transmission in human cervicovaginal explants and humanized mice using CD4 aptamer-siRNA chimeras," The 
Journal of Clinical Investigation, vol. 121, no. 6, pp. 2401-2412, 2011.

[123] M. Takahashi, J. C. Burnett, and J. J. Rossi, "Aptamer-siRNA chimeras for HIV," Advances in Experimental Medicine \& Biology, vol. 848, pp. 211-234, 2015.

[124] P. Zhang, N. Zhao, Z. Zeng, C.-C. Chang, and Y. Zu, "Combination of an aptamer probe to CD4 and antibodies for multicolored cell phenotyping," American Journal of Clinical Pathology, vol. 134, no. 4, pp. 586-593, 2010. 


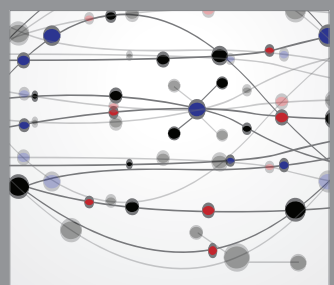

The Scientific World Journal
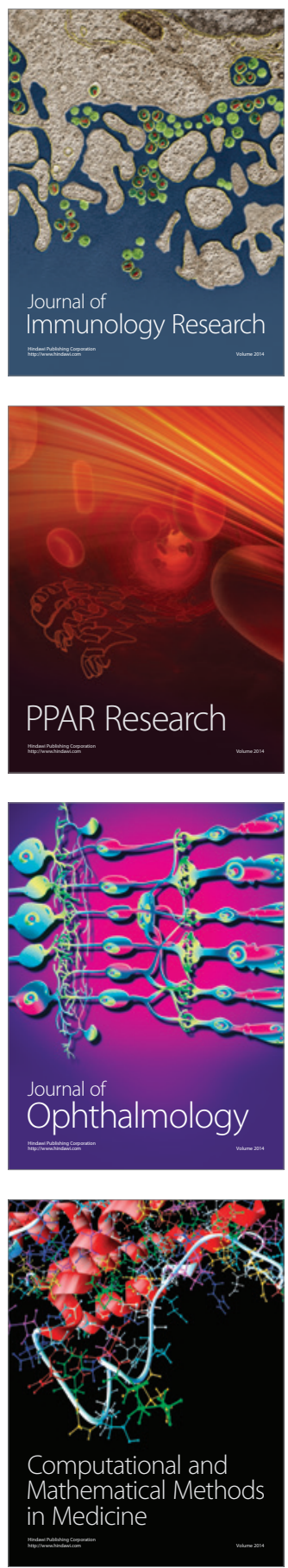

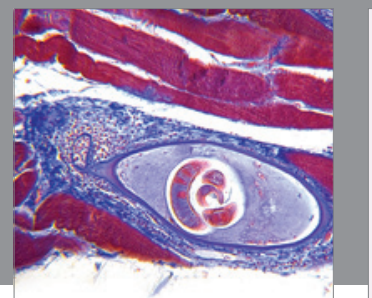

Gastroenterology

Research and Practice
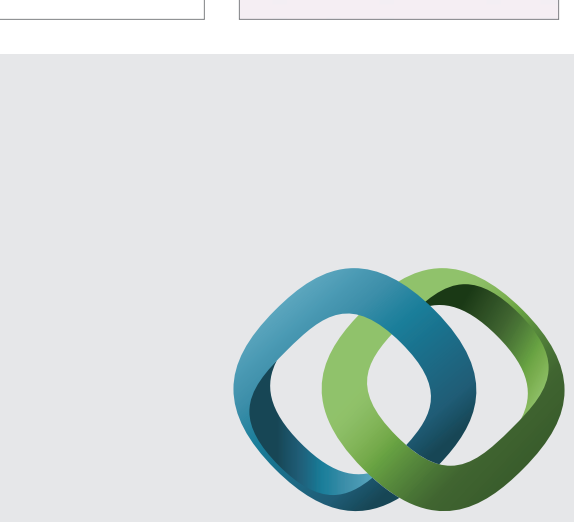

\section{Hindawi}

Submit your manuscripts at

http://www.hindawi.com
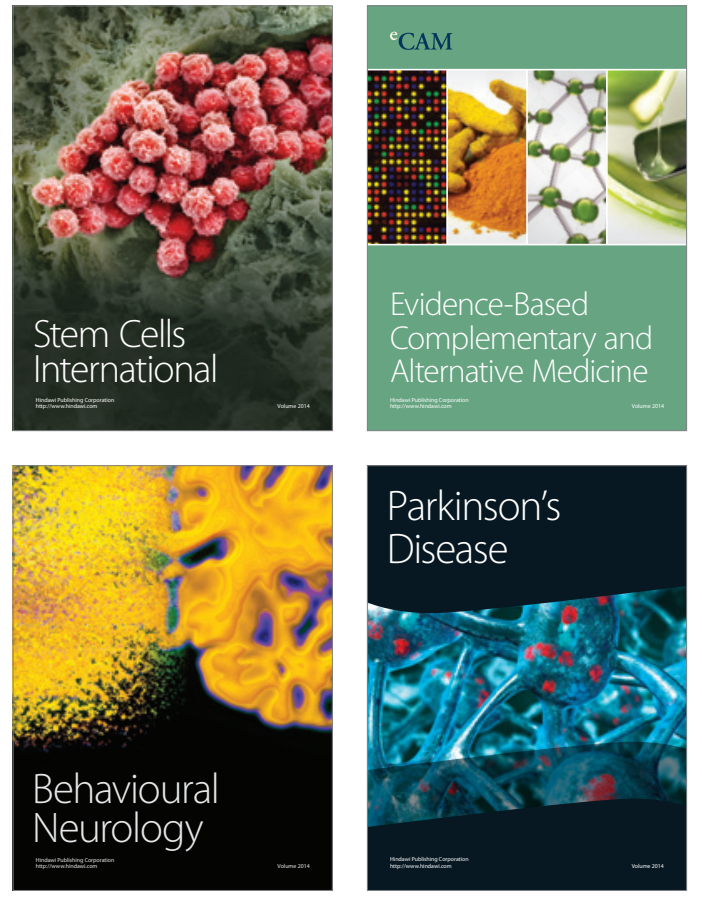
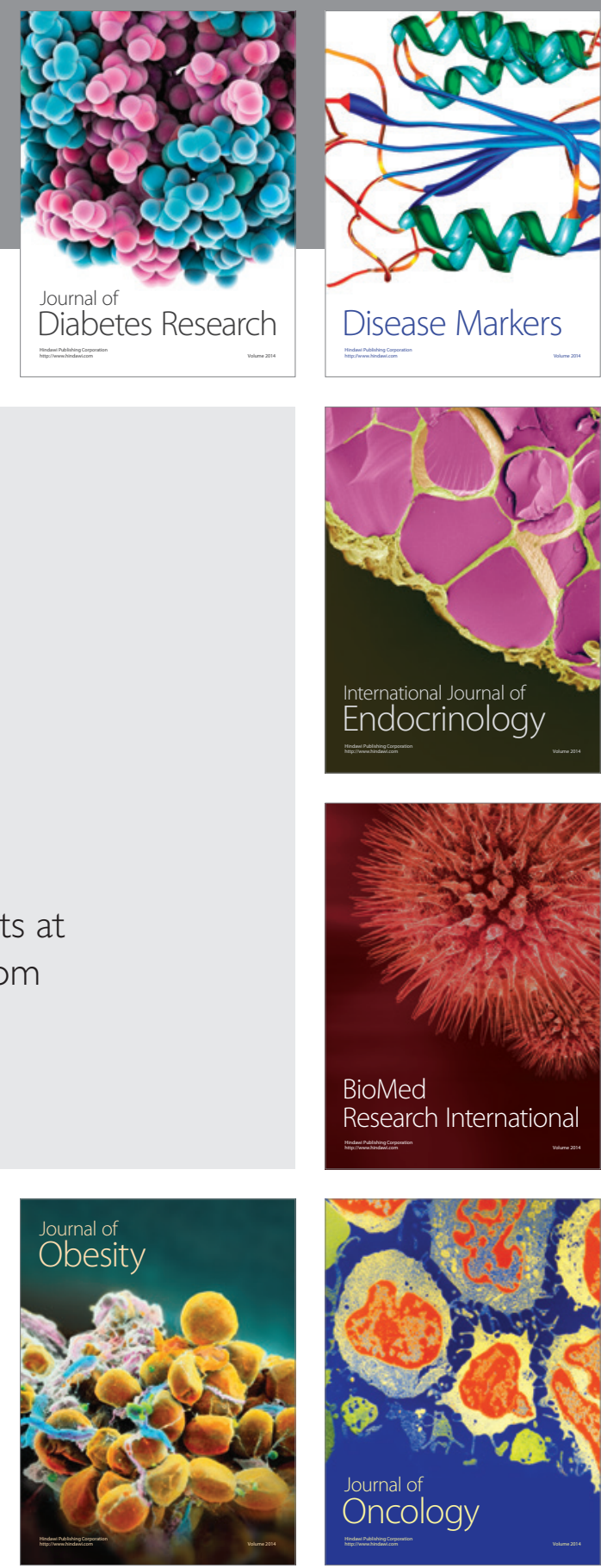

Disease Markers
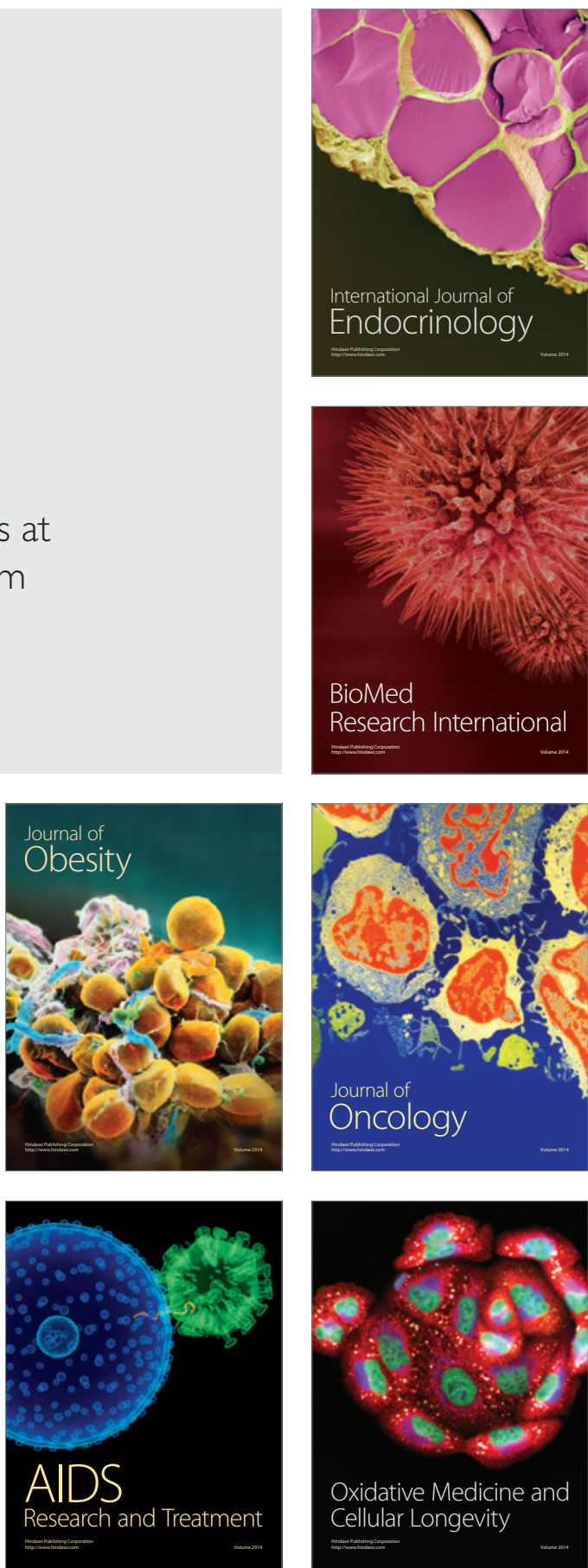